\title{
PENGARUH PENGALAMAN AUDIT, KEAHLIAN AUDIT DAN TEKANAN KETAATAN TERHADAP AUDIT JUDGMENT BPK RI PERWAKILAN PROVINSI SULAWESI UTARA
}

\author{
Christin Lisa Sanger, Ventje Ilat, Winston Pontoh \\ (Email: christin.sanger@yahoo.com)
}

\begin{abstract}
This study aimed to examine the effect of audit experience, audit expertise, and obedience pressure to audit judgment taken by auditor. The sample of this research are auditors who worked on Badan Pemeriksa Keuangan (BPK) RI Representative of Nort Sulawesi Province. The sample was conducted by purposive sampling method. Collecting data was conducted by questionnare distributed directly to auditors as much 50 and only 38 questionnare replayed. Data analysis used multiple linear regression method with SPSS (Statistical Product and Service Solution). The result of this research showed that audit experience significantly affect audit judgment taken by auditor, obedience pressure significantly affect audit judgment taken by auditor, but audit expertise didn't significantly affect audit judgment taken by auditor, because the audit expertise in variabel measurement only use indicator : adetailed knowledge of the financial statements, have the ability to perform an audit in accordance with the regulations and have many types of certification / recognition of the expertise of technical training (does not represent an operational definition of variables). So that the results are less present facts on the ground.
\end{abstract}

Keywords: audit experience, audit expertise, obedience pressure, audit judgment.

\section{PENDAHULUAN}

Dewasa ini, pengguna laporan keuangan pemerintah daerah menuntut adanya transparansi atas penggunaan dana dalam penyelenggaraan pemerintahan daerah. Pengguna laporan keuangan mengharapkan adanya laporan keuangan yang dapat dipercaya, lengkap, dan benar sehingga dapat dijadikan dasar untuk pengambilan keputusan. Atas tuntutan akan pentingnya pengelolaan keuangan yang akuntabel dan transparan maka diterbitkannya PP Nomor 24 Tahun 2005 tentang Standar Akuntansi Pemerintah (SAP) yang kini telah diganti dengan PP Nomor 71 Tahun 2010 oleh Pemerintah.

Selain diwajibkan untuk menyampaikan laporan keuangannya sesuai Standar Akuntansi Pemerintah (SAP), dalam UU Republik Indonesia Nomor 23 Tahun 2014 menyebutkan bahwa pemerintah daerah diwajibkan untuk menyampaikan laporan keuangan sebagai pertanggungjawaban telah berakhirnya tahun anggaran, yang disusun dan disajikan sesuai dengan Standar Akuntansi Pemerintah (SAP) dan wajib diaudit oleh BPK. SAP menjadi pedoman untuk menyatukan persepsi antara penyusun, pengguna, dan auditor. Dengan adanya SAP maka laporan keuangan pemerintah pusat atau daerah akan lebih berkualitas, dapat dipahami, relevan, andal, dan dapat diperbandingkan.

Pemerintah Provinsi Sulawesi Utara dalam Rencana Pembangunan jangka Panjang daerah pada tahun 2025 kedepan baik Provinsi dan Kabupaten Kota semua akan mendapatkan Opini Wajar Tanpa Pengecualian (WTP) dan hal ini sudah mulai ditunjukkan oleh beberapa pemerintah daerah yang dimulai dengan pemerintah Provinsi Sulawesi Utara yang meraih WTP dua kali berturut pada tahun 2009 dan 2010 dan diikuti oleh beberapa Kabupaten Kota yang mendapat Opini WTP serta Kabupaten Kota yang naik peringkat atau terjadi perubahan pengelolaan 
keuangan daerah dari disclaimer menjadi Wajar Dengan Pengecualian (WDP) hingga Wajar Tampa Pengecualian.

Penelitian mengenai audit judgment telah dilakukan oleh beberapa peneliti. Penelitian Chung dan Monroe (2001) yang menguji pengaruh gender dan kompleksitas tugas terhadap audit judgment memberikan kesimpulan bahwa gender dan kompleksitas tugas yang tinggi berpengaruh secara signifikan terhadap judgment yang diambil oleh auditor. Penelitian Herliansyah dan Ilyas (2006) memberikan bukti tambahan bahwa pengalaman berpengaruh terhadap audit judgment. Wijayatri (2010) juga menguji variabel tekanan ketaatan dan keahlian yang memiliki pengaruh signifikan terhadap audit judgment masih ada ketidakkonsistenan dari hasil penelitian mengenai audit judgment di Indonesia. Hal ini dikarenakan judgment auditor merupakan sebuah pertimbangan subyektif dari seorang auditor dan sangat tergantung dari persepsi individu mengenai suatu situasi. Selain itu hasil penelitan terdahulu juga belum dapat digeneralisir untuk seluruh Indonesia dalam pengambilan judgment auditor pada Badan Pemeriksa Keuangan (BPK), sehingga membutuhkan tambahan bukti empiris mengenai faktorfaktor yang dapat mempengaruhi auditor dalam membuat suatu judgment. Hal tersebut mendorong peneliti untuk mengkaji lebih lanjut mengenai, "Pengaruh Pengalaman Audit, Keahlian Audit dan Tekanan Audit terhadap Audit Judgment BPK RI Perwakilan Provinsi Sulawesi Utara. Berdasarkan uraian yang terdapat pada latar belakang masalah, maka permasalahan dapat dirumuskan dalam bentuk pertanyaan sebagai berikut.

1. Apakah pengalaman audit berpengaruh terhadap audit judgment yang diambil oleh auditor?

2. Apakah keahlian audit berpengaruh terhadap audit judgment yang diambil oleh auditor?

3. Apakah tekanan ketaatan berpengaruh terhadap audit judgment yang diambil oleh auditor?

4. Apakah pengalaman audit, keahlian audit dan tekanan ketaatan berpengaruh terhadap audit judgment yang diambil oleh auditor?

\section{TINJAUAN PUSTAKA}

\subsection{Teori Motivasi}

Mc.Clelland mengemukakan motivasi didasarkan dari kekuatan yang ada pada diri manusia adalah motivasi prestasi dimana seseorang dianggap mempuyai apabila dia mempunyai keinginan berprestasi lebih baik dari pada yang lain pada banyak situasi.

\subsection{Teori X dan Y Mcregor}

McGregor mengemukakan dua pandangan mengenai manusia yaitu teori $X$ (negatif) dan teori Y (positif). Seorang auditor pada dasarnya termasuk dalam tipe Y dimana auditor dapat bertanggungjawab terhadap tugasnya sebagai auditor. Dalam melaksanakan tugas pemeriksaan seorang auditor harus mematuhi standar auditing, dimana dalam standar tersebut disebutkan bahwa auditor harus mempertahankan independensi dan tanggung jawabnya dalam semua hal yang berhubungan dengan perikatan. Auditor tidak boleh terpengaruh oleh gangguan yang dapat merusak tanggung jawabnya, baik gangguan pribadi, ekstern, dan organisasi.

\subsection{Teori Penetapan Tujuan}

Teori penetapan tujuan dikemukakan oleh Edwin Locke pada tahun 1990. Teori penetapan tujuan menjelaskan hubungan antara tujuan dengan perilaku apabila seseorang memahami tujuan maka akan terpengaruh kinerjanya. Locke mengemukakan bahwa niat mencapai sebuah tujuan merupakan sumber motivasi kerja yang utama. Tujuan akan memberi tahu seorang individu apa yang harus dilakukan dan berapa banyak usaha yang harus dikeluarkan.

Auditor yang dapat memahami apa yang menjadi tujuannya dan apa yang dia harapkan atas hasil kinerjanya, tidak akan bersikap menyimpang ketika mendapat tekanan dari atasan atau entitas yang diperiksa. Pemahaman mengenai tujuannya dapat membantu auditor membuat suatu audit judgment yang baik. Auditor seharusnya memahami bahwa tugas auditor adalah 
memberikan jasa profesional untuk menilai kewajaran informasi keuangan yang disajikan manajemen kepada masyarakat yang berkepentingan terhadap laporan keuangan tersebut. Melalui pemahaman ini auditor akan tetap bersikap profesional sesuai dengan etika profesi dan standar profesional yang berlaku meskipun menghadapi rintangan dalam tugas auditnya.

2.4. Teori Kognitif

Psikologi kognitif menjelaskan bahwa perilaku manusia tidak ditentukan oleh stimulus yang berada diluar dirinya, melainkan oleh faktor yang ada pada dirinya sendiri. Faktor internal tersebut berupa kemampuan atau potensi yang berfungsi untuk mengenal dunia luar, dan dengan pengenalan itu manusia mampu memberikan respon terhadap stimulus. Berdasarkan pada pandangan itu, teori kognitif memandang belajar sebagai proses pemfungsian unsur-unsur kognisi terutama pikiran untuk mengenal dan memahami stimulus yang datang dari luar.Dengan kata lain, aktivitas belajar manusia ditentukan pada proses internal dalam berpikir yakni pengolahan informasi.

Teori kognitif dapat digunakan untuk mengkaji bagaimana auditor mengambil suatu pertimbangan berdasarkan pengalaman dan keahliannya dalam melaksanakan tugas audit. Ketika pengalaman audit seorang auditor bertambah maka judgment yang dibuat akan lebih berkualitas Setiap kali auditor melakukan audit maka auditor akan belajar dari pengalaman sebelumnya, memahami serta meningkatkan kecermatan dalam pelaksanaan audit. Auditor akan mengintegrasikan pengalaman auditnya dengan pengetahuan yang telah dimilikinya. Proses memahami dan belajar inilah yang menjadi proses peningkatan keahlian auditor. Auditor yang berpengalaman dan didukung keahlian dalam mengaudit dapat menghasilkan judgment yang lebih berkualitas dibandingkan dengan auditor yang tidak berpengalaman dan tidak mempunyai keahlian audit.

\subsection{Standar Pemeriksaan Keuangan Negara (SPKN)}

Standar Pemeriksaan merupakan patokan bagi para pemeriksa dalam melakukan tugas pemeriksaannya. SPKN ini ditetapkan dengan peraturan BPK Nomor 01 Tahun 2007 sebagaimana amanat UU yang ada. Sejak ditetapkannya Peraturan BPK ini dan dimuatnya dalam Lembaran Negara, SPKN akan mengikat BPK, akuntan publik dan pihak lainnya yang melakukan pemeriksaan atas pengelolaan dan tanggung jawab keuangan negara untuk dan atas nama BPK. Tujuan dari SPKN adalah untuk menjadi ukuran mutu bagi para pemeriksa dan organisasi pemeriksa dalam melaksanakan pemeriksaan atas pengelolaan dan tanggung jawab keuangan negara, sehingga diharapkan hasil pemeriksaan BPK dapat lebih berkualitas yaitu memberikan nilai tambah yang positif bagi pengelolaan dan tanggung jawab keuangan negara dan akan berdampak pada peningkatan kesejahteraan hidup masyarakat Indonesia.

\subsection{Kode Etik Pemeriksa}

Peraturan BPK RI Nomor 02 Tahun 2011 tentang kode etik BPK RI mulai diberlakukan sejak tanggal 7 Oktober 2011. Kode Etik bertujuan untuk memberikan pedoman yang wajib ditaati oleh Anggota BPK, Pemeriksa, dan Pelaksana BPK lainnya untuk mewujudkan BPK yang berintegritas, independen, dan profesional demi kepentingan negara. Kode Etik harus diwujudkan dalam sikap, ucapan, dan perbuatan Anggota BPK, Pemeriksa, dan Pelaksana BPK Lainnya selaku Aparatur Negara/Pejabat Negara dalam melaksanakan pemeriksaan dan dalam kehidupan sehari-hari, baik selaku individu dan anggota masyarakat, maupun selaku warga Negara.

\subsection{Audit judgment}

Audit judgment merupakan suatu pertimbangan pribadi atau cara pandang auditor dalam menanggapi informasi yang mempengaruhi dokumentasi bukti serta pembuatan keputusan 
pendapat auditor atas laporan keuangan suatu entitas. Jamilah, dkk (2007) menyatakan audit judgment adalah kebijakan auditor dalam menentukan pendapat mengenai hasil auditnya yang mengacu pada pembentukan suatu gagasan, pendapat atau perkiraan tentang suatu objek, peristiwa, status, atau jenis peristiwa lainnya. Setiap langkah dalam proses incremental judgment, jika informasi terus menerus datang akan muncul pertimbangan baru dan keputusan atau pilihan baru.

Audit judgment diperlukan karena audit tidak dilakukan terhadap seluruh bukti. Bukti inilah yang digunakan untuk menyatakan pendapat atas laporan keuangan auditan, sehingga dapat dikatakan bahwa audit judgment ikut menentukan hasil dari pelaksanaan audit. Rochmawati (2009) menjelaskan tahapan-tahapan yang dilakukan pada saat melakukan audit judgment yaitu merumuskan persoalan, mengumpulkan informasi yang relevan, mencari alternatif tindakan, menganalisis alternatif yang fleksibel, memilih alternatif yang terbaik, kemudian pelaksanaan dan evaluasi hasilnya.

2.8. Pengalaman Audit

Pengalaman merupakan suatu proses pembelajaran dan pertambahan perkembangan potensi bertingkah laku (Anugrah, 2012). Pengalaman seseorang dapat diartikan sebagai suatu proses yang dapat membawa seseorang kepada suatu pola tingkah laku yang lebih tinggi. Pengalaman dapat memberikan peluang bagi seseorang untuk melakukan pekerjaan dengan lebih baik. Semakin luas pengalaman kerja seseorang, semakin trampil melakukan pekerjaan dan semakin sempurna pola berpikir dan sikap dalam bertindak untuk mencapai tujuan yang telah ditetapkan (Puspaningsih, 2004).

. Pengalaman audit adalah pengalaman yang dimiliki oleh seorang auditor dalam melakukan audit atas laporan keuangan suatu entitas. Abdolmohammadi dan Wright (1987) menemukan bahwa judgment auditor yang tidak berpengalaman mempunyai tingkat populasi kesalahan yang secara signifikan lebih besar dibandingkan auditor berpengalaman. Semakin berpengalaman seorang auditor maka dia akan semakin mampu dalam menghasilkan kinerja yang lebih baik dalam melakukan pemeriksaan.

2.9. Keahlian Audit

Dalam Standar pemeriksaan Pernyataan Nomor 01 Tentang Standar Umum pada paragraph 11 menyebutkan bahwa keahlian yang dibutuhkan dalam tugas pemeriksaan keuangan adalah keahlian di bidang akuntansi dan auditing, memahami prinsip akuntansi yang berlaku umum yang berkaitan dengan entitas yang diperiksa, dan memiliki sertifikasi. Secara kolektif pemeriksa harus membagi tugas pemeriksaan sesuai keahlian masing-masing dan mendapatkan komitmen dari anggota pemeriksa akan peran mereka dalam penyelesaian tugas dan memenuhi harapan pemberi tugas agar dapat dilaksanakan pemeriksaan yang efektif dan efisien.

Keahlian merupakan unsur penting yang harus dimiliki oleh seorang auditor independen untuk bekerja sebagai tenaga profesional (Asih, 2006). Keahlian audit mencakup antara lain: merencanakan pemeriksaan, melaksanakan program kerja pemeriksaan, menyusun kertas kerja, menyusun berita pemeriksaan, dan laporan hasil pemeriksaan. Keahlian auditor dalam melakukan audit menunjukkan tingkat kemampuan dan pengetahuan yang dimiliki auditor.

\subsection{Tekanan Ketaatan}

Tekanan ketaatan pada umumnya dihasilkan oleh individu yang memiliki kekuasaan. Dalam hal ini tekanan ketaatan diartikan sebagai tekanan yang diterima oleh auditor junior dari auditor senior atau atasan dan entitas yang diperiksa untuk melakukan tindakan yang menyimpang dari standar etika dan profesionalisme. Intruksi atasan dalam suatu organisasi akan mempengaruhi perilaku bawahan karena atasan memiliki otoritas (Grediani dan Slamet, 2007). 
Pengaruh dari tekanan ketaatan biasanya dialami oleh auditor pemula, karena mereka biasanya masih cenderung untuk menaati perintah atasan maupun entitas yang diperiksa meskipun perintah tersebut tidak benar bahkan dapat melanggar standar profesional. Tekanan ketaatan dapat menghasilkan variasi pada judgment auditor dan memperbesar kemungkinan pelanggaran standar etika dan profesional.

\section{Hipotesis dan Model}

Kerangka pikir dari penelitian "Pengaruh Pengalaman Audit, Keahlian Audit dan Tekanan Ketaatan Terhadap Audit Judgment BPK RI Perwakilan Provinsi Sulawesi Utara" adalah sebagai berikut:

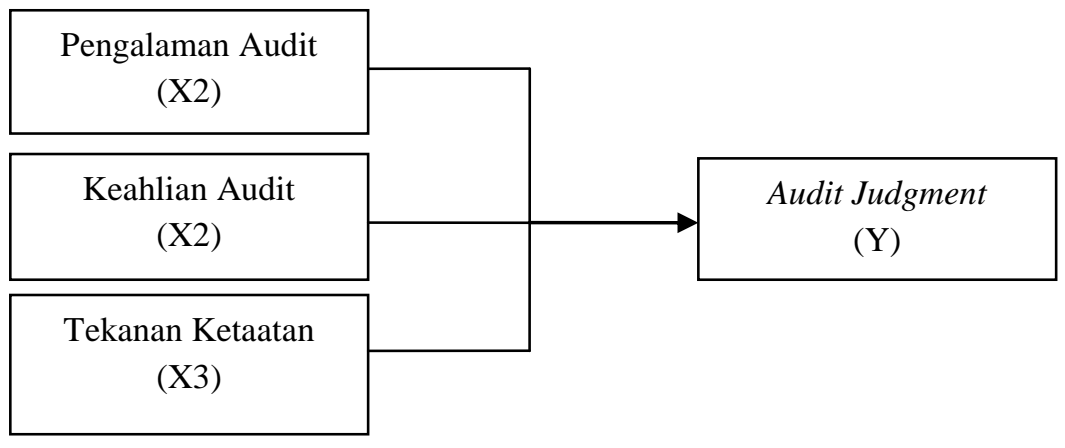

Gambar 1. Kerangka Model

Berdasarkan penjelasan tersebut, maka dalam peneilitian ini akan dirumuskan hipotesis sebagai berikut :

H1 : Pengalaman audit berpengaruh terhadap judgment yang diambil oleh auditor.

$\mathrm{H} 2$ : Keahlian audit berpengaruh terhadap judgment yang diambil oleh auditor.

H3 : Tekanan ketaatan berpengaruh terhadap judgment yang diambil oleh auditor.

H4 : Pengalaman audit, keahlian audit dan tekanan ketaatan berpengaruh terhadap judgment yang diambil oleh auditor.

\section{METODE PENELITIAN}

4.1. Data

Populasi penelitian ini adalah seluruh auditor eksternal Badan Pemeriksa Keuangan (BPK) RI Perwakilan Provinsi Sulawesi Utara yang. Pada penelitian ini menggunakan sampel. Besarnaya sampel yang diambil adalah menggunakan prinsip sampel besar yaitu menurut statistik sampel besar adalah minimal 30. Pada penelitian ini jumlah sampel yang diambil sebesar 50 pemeriksa (syarat ini telah memenuhi sampel minimal).

4.2. Variabel dan Pengukuran Variabel

Pada penelitian ini indikator yang digunakan untuk mengukur audit judgment (Y) adalah sebagai berikut :

1. Materialitas adalah salah saji dalam laporan keuangan

2. Perekayasaan transaksi oleh entitas adalah kemampuan pemeriksa untuk mendeteksi adanya perekayasaan transasksi oleh entitas.

3. Memperluas pengujian berdasarkan bukti audit adalah keinginan yang besar dari pemeriksa untuk melakukan pendalaman terhadap bukti yang ada.

Variabel Independen 
Pengalaman audit adalah pengalaman yang dimiliki oleh auditor dalam menjalankan profesinya sebagai auditor eksternal pemerintah. Variabel ini diukur dengan menggunakan indikator yang dikembangkan oleh Susetyo (2009).

Pada penelitian ini indikator yang digunakan untuk mengukur pengalam audit (X1) adalah sebagai berikut:

1. Intensitas Penugasan audit adalah persepsi dari pemeriksa terhadap banyak sedikitnya penugasan audit dilapangan.

2. Intensitas lama waktu audit adalah persepsi dari pemeriksa terhadap lamanya waktu melaksanakan masa penugasan.

3. Tugas diberbagai daerah adalah persepsi pemeriksa bahwa tugas diberbagai tempat penting bagi keahlian diri.

Pada penelitian ini indikator yang digunakan untuk mengukur keahlian audit (X2) adalah sebagai berikut :

1. Pengetahuan auditor adalah kemampuan mengetahui secara detail laporan keuangan dari entitas.

2. Kemampuan melakukan audit adalah kemampuan pemeriksa melakukan sesuai dengan peraruran

3. Sertifikasi /pengukuran keahlian adalah persepsi atas banyaknya pelatihan teknis yang diikuti.

Pada penelitian ini indikator yang digunakan untuk mengukur tekanan ketaatan (X3) adalah sebagai berikut :

1. Instruksi atasan adalah intensitas kuatnya pemeriksaan untuk patuh dan taat pada instruksi atasan. (Grediani dan Slamet, 2007)

2. Perubahan Psikologis adalah tetap konsisten walau bekerja dalam tekanan. (Hartanto, 2011)

3. Standar etika adalah tetap berpegang pada standar-standar moral walaupun bekerja dalam tekanan.

Semua indikator pada penelitian ini menggunakan skala likert menurut Sugiyono (2014), skala likert digunakan untuk mengukur sikap, pendapat dan persepsi seseorang atau sekelompok orang tentang fenomena sosial. Jawaban setiap item instrumen yang menggunakan skala likert mempunyai gradasi dari sangat positif sampai sangat negatif. Dengan nilai terendah 1 dan tertinggi 5 dengan klasifikasi sebagai berikut : sangat setuju 5, setuju 4, netral 3, tidak setuju 2, sangat tidak setuju 1.

Metode analisis yang digunakan untuk menguji hipotesis adalah metode regresi berganda (multiple regression) dengan persamaan regresi sebagai berikut:

\section{HASIL ANALISIS DAN PEMBAHASAN}

$$
Y=a+\beta_{1} X_{1}+\beta_{2} X_{2}+\beta_{3} X_{3}+\beta_{4} X_{4}+e
$$

Hasil Analisis Regresi

$$
Y=2,293+0,495 X_{1}+0,030 X_{2}+0,330 X_{3}+\varepsilon
$$

Persamaan regresi berganda di atas dapat dijelaskan sebagai berikut:

1. Menunjukkan bahwa pengalaman audit memiliki pengaruh positif terhadap audit judgment yang diambil oleh auditor dilihat dari nilai koefisien regresi sebesar 0,495.

2. Menunjukkan bahwa keahlian audit memiliki pengaruh positif terhadap audit judgment yang diambil oleh auditor dilihat dari nilai koefisien regresi sebesar 0,030.

3. Menunjukkan bahwa tekanan ketaatan memiliki pengaruh positif terhadap audit judgment yang diambil oleh auditor dilihat dari nilai koefisien regresi sebesar 0,330 . 
4. Nilai intersep sebesar 2,293 menunjukkan bahwa apabila pengalaman audit, keahlian audit dan tekanan ketaatan dianggap konstan, maka audit judgment akan bertambah sebesar 2,520 satuan.

Pengujian Hipotesis Secara Simultan (Uji F)

Melalui uji statistik secara simultan, menunjukkan bahwa $F_{\text {hitung }}=11,746$, sehingga $F_{\text {hitung }}=$ $11,746>\mathrm{F}_{\text {tabel }}=2,88$ juga dapat dilihat tingkat signifikansi adalah $0,000<0,005$ atau dibawa 5\% ataupun $1 \%$. Hasil pengujian ini menunjukkan bahwa variabel pengalaman audit, keahlian audit dan tekanan ketaatan secara bersama-sama berpengaruh secara signifikan terhadap variabel audit judgment.

Pengujian Hipotesis Secara Parsial (Uji t)

Pengaruh pengalaman audit $(\mathrm{X} 1)$ terhadap audit judgment Nilai $t_{\text {hitung }}$ dari variabel pengalaman audit adalah 2,945, sehingga:

$\mathrm{t}_{\text {hitung }}=2,945>\mathrm{t}_{\text {tabel }}=2,03224$

1. Signifikansi dari variabel pengalaman audit adalah sebesar $0,006<0,05$.

2. Hal ini menunjukkan bahwa $\mathrm{Ha}_{1}$ diterima dan $\mathrm{Ho}_{1}$ ditolak, sehingga terbukti bahwa pengalaman audit berpengaruh positif dan signifikan terhadap audit judgment.

Pengaruh keahlian audit (X2) terhadap audit judgment

1. Nilai $t_{\text {hitung }}$ dari variabel keahlian audit adalah 0,275 , sehingga:

$\mathrm{t}_{\text {hitung }}=0,275<\mathrm{t}_{\text {tabel }}=2,03224$

2. Signifikansi dari variabel keahlian audit adalah sebesar 0,785 >0,05.

3. Hal ini menunjukkan bahwa $\mathrm{Ha}_{2}$ ditolak dan $\mathrm{Ho}_{2}$ diterima, sehingga tidak terbukti bahwa keahlian audit berpengaruh secara signifikan terhadap audit judgment. Jadi, keahlian audit tidak berpengaruh terhadap audit judgment.

Pengaruh tekanan ketaatan (X3) terhadap audit judgment

1. Nilai $t_{\text {hitung }}$ dari variabel pengalaman audit adalah 2,172, sehingga:

$t_{\text {hitung }}=2,172>t_{\text {tabel }}=2,03224$

2. Signifikansi dari variabel tekanan ketaatan adalah sebesar $0,037<0,05$.

3. Hal ini menunjukkan bahwa $\mathrm{Ha}_{3}$ diterima dan $\mathrm{Ho}_{3}$ ditolak, sehingga terbukti bahwa tekanan ketaatan berpengaruh positif dan signifikan terhadap audit judgment.

Uji Koefisien Korelasi (R) dan Koefisien Determinasi (adjusted R2)

Hasil uji koefisien korelasi yang dihasilkan antara variabel independent pegalaman audit (X1), keahlian audit (X2) dan tekanan ketaatan (X3) dengan variabel audit judgment (Y) adalah sebesar 0,713 artinya ketiga variabel independen secara bersama-sama memiliki hubungan yang kuat sebesar $71,3 \%$. Hasil perhitungan koefisien determinasi dalam penelitian ini tampak bahwa nilai koefisien determinasi adalah 0,466. Hal ini menunjukkan bahwa besarnya pengaruh variabel bebas, yaitu pengalaman audit, keahlian audit, tekanan ketaatan terhadap variabel terikat yaitu audit judgment yang diterangkan oleh model persamaan dalam penelitian ini adalah sebesar 47\%, sedangkan sisanya sebesar 53\% disebabkan oleh faktor-faktor lain diluar pengujian ini.

\subsection{Pembahasan}

5.2.1Pengaruh Pengalaman Audit (X1) terhadap Audit Judgemen (Y)

Hasil pengujian hipotesis pertama menunjukkan bahwa pada variabel Pengalaman audit, $\mathrm{t}_{\text {hitung }}=2,945>\mathrm{t}_{\text {tabel }}=2,232$ sehingga pengalaman audit berpengaruh secara signifikan terhadap audit judgment yang diambil oleh Auditor BPK RI Perwakilan Provinsi Sulawesi Utara. Hasil penelitian ini menunjukkan bahwa semakin tinggi pengalaman audit yang dimiliki oleh seorang auditor maka judgment yang diambil auditor juga akan semakin baik dan tepat. Banyaknya 
pengalaman dalam bidang audit dapat membantu auditor dalam memahami dan menyelesaikan masalah yang cenderung mempunyai pola yang sama.

Berdasarkan teori kognitif, praktik-praktik dalam bidang auditing sebagai auditor independen dapat menjadi sarana pembelajaran dan pengalaman bagi auditor. Auditor akan mengintegrasikan pengalaman serta pengetahuan yang dimilikinya dalam melaksanakan tugas yang akan datang. Dibidang audit, pengalaman auditor merupakan faktor penting yang dibutuhkan dalam menyelesaikan pekerjaannya. Pengalaman audit adalah pengalaman yang dimiliki oleh seorang auditor dalam melakukan audit atas laporan keuangan suatu entitas. Sehingga semakin berpengalaman seorang auditor maka dia akan semakin mampu dalam menghasilkan kinerja yang lebih baik dalam tugas pemeriksaan setiap kali auditor melakukan audit maka auditor akan belajar dari pengalaman audit sebelumnya dan meningkatkan kecermatan serta memperkaya pengetahuan dalam pelaksanaan audit sehingga judgment yang diambil oleh auditor tersebut akan semakin berkualitas.

Hasil penelitian ini mendukung penelitian yang dilakukan oleh Rahmawati (2016) yang menganalisis faktor-faktor yang mempengaruhi auditor dalam melakukan Audit Judgment pada Kantor Akuntan Publik di Jawa Tengah dan DIY disimpulkan bahwa semakin tinggi pengalaman auditor maka judgment yang diambil oleh auditor cenderung tepat. Didukung juga oleh Praditaningrum (2012), menganalisis faktor-faktor yang berpengaruh terhadap audit judgment pada BPK RI Perwakilan Provinsi Jawa Tengah disimpulkan bahwa Pengalaman audit yang tinggi dapat memberikan kenaikan audit judgment, penelitian Zulaikha (2006) menjelaskan bahwa pengalaman auditor memiliki main effect terhadap pertimbangan audit, dimana dalam penugasan audit utamanya perlu memperhatikan pengalamannya sebagai auditor.

5.2.3. Keahlian audit (X2) terhadap Audit Judgemen (Y)

Hasil pengujian hipotesis kedua menunjukkan bahwa pada variabel keahlian audit, $\mathrm{t}_{\text {hitung }}=$ $0,275<\mathrm{t}_{\text {tabel }}=2,032$ sehingga keahlian audit tidak berpengaruh terhadap audit judgment yang diambil oleh BPK RI Perwakilan Provinsi Sulawesi Utara. Hasil pengujian ini menunjukan bahwa keahlian audit oleh seorang auditor tidak berpengaruh terhadap judgment.

Dalam Standar pemeriksaan Pernyataan Nomor 01 Tentang Standar Umum pada paragraph 11 menyebutkan bahwa keahlian yang dibutuhkan dalam tugas pemeriksaan keuangan adalah keahlian di bidang akuntansi dan auditing, memahami prinsip akuntansi yang berlaku umum yang berkaitan dengan entitas yang diperiksa, dan memiliki sertifikasi. Secara kolektif pemeriksa harus membagi tugas pemeriksaan sesuai keahlian masing-masing dan mendapatkan komitmen dari anggota pemeriksa akan peran mereka dalam penyelesaian tugas dan memenuhi harapan pemberi tugas agar dapat dilaksanakan pemeriksaan yang efektif dan efisien.

Keahlian dapat diartikan sebagai keberadaan dari pengetahuan tentang suatu lingkungan tertentu, pemahaman terhadap masalah yang timbul dari lingkungan tersebut dan ketrampilan untuk memecahkan masalah tersebut sehingga auditor dapat mengerjakan pekerjaan secara mudah, cepat, intuisi, dan sangat jarang atau tidak pernah membuat kesalahan.

Keahlian merupakan unsur penting yang harus dimiliki oleh seorang auditor independen untuk bekerja sebagai tenaga profesional. Kemampuan dan pengetahuan auditor di bidang auditing dapat diperoleh melalui pendidikan formal maupun keikutsertaan dalam pelatihan atau seminar sehingga auditor dapat merencanakan pemeriksaan, melaksanakan program kerja pemeriksaan, menyusun kertas kerja, menyusun berita acara pemeriksaan, dan laporan hasil pemeriksaan. Selain itu keahlian auditor juga dapat bertambah seiring dengan pengalaman kerja maupun praktek audit yang telah dilakukannya. 
Hasil penelitian ini bertentangan dengan penelitian Drupadi (2015) yang menganalisis pengaruh keahlian auditor, tekanan ketaatan dan independensi pada udit judgment auditor KAP di wilayah Bali disimpulkan bahwa semakin tinggi keahlian seorang auditor maka semakin akurat audit judgment yang dihasilkan. Keahlian seorang auditor dapat meningkat dengan tinggi pendidikan dan banyaknya pengalaman dan pengetahuan yang dimiliki auditor. Begitu pula dengan penelitian Mayangsari (2003) yang menyatakan bahwa auditor yang mempunyai pemahaman dan pengetahuan yang lebih baik atas laporan keuangan, akan lebih mampu memberikanan penjelasan yang masuk akal atas kesalahan-kesalahan dalam laporan keuangan dan penelitian Waspodo (2007) juga menyatakan auditor yang berpendidikan tinggi akan mempunyai pandangan yang lebih luas mengenai berbagai hal.

5.2.4. Tekanan Ketaatan (X3) terhadap Audit Judgemen (Y)

Hasil pengujian hipotesis ketiga menunjukkan bahwa pada variabel tekanan ketaatan, $t_{\text {hitung }}=$ 2,172> $\mathrm{t}_{\text {tabel }}=2,032$ sehingga tekanan ketaatan berpengaruh secara signifikan terhadap audit judgment yang diambil oleh auditor BPK RI Perwakilan Provinsi Sulawesi Utara.

Tekanan ketaatan pada umumnya dihasilkan oleh individu yang memiliki kekuasaan. Dalam hal ini tekanan ketaatan diartikan sebagai tekanan yang diterima oleh auditor junior dari auditor senior atau atasan dan entitas yang diperiksa untuk melakukan tindakan yang menyimpang dari standar etika dan profesionalisme. Intruksi atasan dalam suatu organisasi akan mempengaruhi perilaku bawahan karena atasan memiliki otoritas.

Pengaruh dari tekanan ketaatan biasanya dialami oleh auditor pemula, karena mereka biasanya masih cenderung untuk menaati perintah atasan maupun entitas yang diperiksa meskipun perintah tersebut tidak benar bahkan dapat melanggar standar profesional. Tekanan ketaatan dapat menghasilkan variasi pada judgment auditor dan memperbesar kemungkinan pelanggaran standar etika dan profesional.

Berdasarkan teori penetapan tujuan, auditor yang tidak mengetahui dengan pasti tujuannya biasanya cenderung mudah berperilaku menyimpang dengan menuruti perintah dari atasan dan entitas yang diperiksa untuk berperilaku menyimpang dari standar etika dan profesional. Hal ini akan mengakibatkan auditor tidak mampu membuat judgment yang baik dan tepat.

Hasil penelitian ini mendukung penelitian yang dilakukan oleh Hartanto (2000) menunjukkan bukti bahwa auditor yang mendapatan perintah tidak tepat baik itu dari atasan ataupun dari klien cenderung akan berperilaku menyimpang dari standar profesional sehingga mengakibatkan tekanan ketaatan berpengaruh secara signifikan terhadap judgment yang diambil oleh auditor. Penelitian Jamilah,dkk. (2007) juga memberikan bukti bahwa tekanan ketaatan dapat mempengaruhi auditor dalam membuat suatu judgment. Hal ini berarti semakin tinggi tekanan ketaatan yang diterima oleh auditor maka judgment yang diambil oleh auditor akan semakin tidak baik dan tidak tepat.

5.2.5. Pengalaman Audit (X1), Keahlian Audit(X2) dan Tekanan Ketaatan (X3) terhadap Audit Judgemen (Y)

Hasil pengujian hipotesis keempat menunjukkan bahwa $F_{\text {hitung }}=11,746$, sehingga $F_{\text {hitung }}=$ $11,746>\mathrm{F}_{\text {tabel }}=2,88$ juga dapat dilihat tingkat signifikansi adalah $0,000<0,005$ atau dibawa $5 \%$ ataupun $1 \%$. Hasil pengujian ini menunjukkan bahwa pengalaman audit, keahlian audit dan tekanan ketaatan secara bersama-sama berpengaruh secara signifikan terhadap audit judgment yang diambil oleh auditor BPK RI Perwakilan Provinsi Sulawesi Utara.

Pengalaman mengarah kepada proses pembelajaran dan pertambahan potensi bertingkah laku dari pendidikan formal maupun nonformal. Pengalaman juga bisa dikatakan sebagai proses yang membawa seseorang menuju kepada suatu pola tingkah laku yang lebih tinggi. Semakin 
berpengalaman seorang auditor maka dia akan semakin mampu dalam menghasilkan kinerja yang lebih baik dalam tugas pemeriksaan setiap kali auditor melakukan audit maka auditor akan belajar dari pengalaman audit sebelumnya dan meningkatkan kecermatan serta memperkaya pengetahuan dalam pelaksanaan audit sehingga judgment yang diambil oleh auditor tersebut akan semakin berkualitas.

Keahlian auditor mengarah pada tingkat kemampuan dan pengetahuan yang dimiliki auditor. Kemampuan dan pengetahuan auditor di bidang auditing dapat diperoleh melalui pendidikan formal maupun keikutsertaan dalam pelatihan atau seminar. Keahlian auditor juga dapat bertambah seiring dengan pengalaman kerja maupun praktek audit yang telah dilakukannya sehingga judgment yang diambil oleh auditor tersebut akan semakin berkualitas.

Tekanan ketaatan mengarah kepada tekanan yang didapatkan dari atasan dan juga tekanan yang berasal dari entitas yang diperiksa. Entitas yang diperiksa mempengaruhi proses pemeriksaan dan menekan auditor untuk mengambil tindakan yang melanggar standar pemeriksaan. Situasi ini membuat auditor dalam situasi konflik, dimana auditor berusaha untuk memenuhi tanggung jawab profesionalnya yang harus dilandasi oleh keterbukaan, kejujuran, integritas dan menjunjung praktek yang fair dan bermoral tetapi disisi lain dituntut pula untuk mematuhi perintah dari entitas yang diperiksa maupun dari atasannya. Adanya tekanan untuk taat dapat membawa dampak pada judgment yang diambil oleh auditor. Semakin tinggi tekanan yang dihadapi oleh auditor maka judgment yang diambil oleh auditor cenderung kurang tepat.

Hasil penelitian ini mendukung penelitian yang dilakukan oleh Praditaningrum (2012), menganalisis faktor-faktor yang berpengaruh terhadap audit judgment yang menyatakan bahwa pengalaman audit, keahlian audit dan tekanan ketaatan secara bersama-sama berpengaruh terhadap audit judgment.

\section{KESIMPULAN DAN SARAN}

Kesimpulan

Penelitian ini meneliti pengaruh pengalaman audit, keahlian audit dan tekanan ketaatan terhadap audit judgment. Auditor pada penelitian ini yaitu auditor yang ada di BPK RI Perwakilan Provinsi Sulawesi Utara. Data primer diperoleh melalui kuesioner yang disebarkan kepada 38 orang auditor. Kuesioner diolah menggunakan alat statistik SPSS.

Berdasarkan hasil uji hipotesis yang telah dilakukan, maka dapat disimpulkan bahwa:

a. Pengalaman audit (X1) berpengaruh secara signifikan terhadap audit judgment (Y). Nilai koefisien regresi pengalaman audit sebesar 0,495 satuan. Auditor akan mengintegrasikan pengalaman serta pengetahuan yang dimilikinya dalam melaksanakan tugas yang akan datang. Dibidang audit, pengalaman auditor merupakan faktor penting yang dibutuhkan dalam menyelesaikan pekerjaannya. Semakin berpengalaman seorang auditor maka dia akan semakin mampu dalam menghasilkan kinerja yang lebih baik dalam tugas-tugas pemeriksaan.

b. Keahlian audit (X2) tidak berpengaruh terhadap audit judgment (Y). Nilai koefisien regresi pengalaman audit sebesar 0,030. Hasil pengujian ini menunjukan bahwa keahlian audit oleh seorang auditor tidak berpengaruh terhadap judgment. Kondisi ini menunjukkan bahwa seharusnya seorang auditor independen untuk bekerja sebagai tenaga profesional harus memiliki keahlian audit sehingga dapat menghasilkan judgment yang semakin akurat.

c. Tekanan ketaatan (X1) berpengaruh secara signifikan terhadap audit judgment (Y). Nilai koefisien regresi tekanan ketaatan sebesar 0,330. Auditor yang mendapakan tekanan ketaatan yang besar dari atasan dan entitas yang diperiksa akan cenderung untuk berperilaku menyimpang dan menghasilkan audit judgment yang tidak baik dan kurang tepat. 
d. Pengalaman audit (X1), keahlian audit (X2) dan tekanan ketaatan (X3) secara bersama-sama berpengaruh secara signifikan terhadap audit judgment $(\mathrm{Y})$. Nilai $\mathrm{F}_{\text {hitung }}=11,746$, sehingga $\mathrm{F}_{\text {hitung }}=11,746>\mathrm{F}_{\text {tabel }}=2,88$ juga dapat dilihat tingkat signifikansi adalah $0,000<0,005$ atau dibawa $5 \%$ ataupun $1 \%$.

e. Hubungan antara Variabel independen (X) terhadap variabel dependen (Y) memiliki hubungan yang kuat sebesar $71,3 \%$.

f. Pengaruh variabel independen (X) terhadap variabel (Y) sebesar 0,466 (47\%) sisanya dipengaruhi oleh faktor-faktor lain diluar pengujian ini.

Keterbatasan dan Saran

a. Dalam pengukuran variabel Keahlian audit hanya menggunakan indikator memiliki pengetahuan secara detail atas laporan keuangan, memiliki kemampuan kemampuan melalukan audit sesuai dengan peraturan dan memiliki banyak jenis sertifikasi/pengakuan keahlian dari pelatihan teknis (tidak mewakili definisi operasional variabel). Sehingga hasil yang didapat kurang merepresentasikan fakta yang ada di lapangan.

b. Waktu pembagian kuesioner dilakukan pada saat waktu pemeriksaan auditor BPK RI Perwakilan Provinsi Sulawesi Utara sehingga pengembalian kuesioner tidak maksimal.

c. Saran untuk penelitian berikutnya supaya dalam pembagian kuesioner jangan pada saat pemeriksaan dan peneliti selanjutnya diharapkan dapat memperluas sampel penelitian, tidak hanya BPK RI Perwakilan Provinsi Sulawesi Utara supaya hasil dapat digeneralis.

\section{DAFTAR PUSTAKA}

Abdolmohammadi, M dan A. Wright. 1987. An Examination of The Effect of Experience and Task Complexcity on Audit judgment., Journal of The Accounting Review, 62 : 1-13.

Asih, Dwi Ananing Tyas. 2006. "Pengaruh Pengalaman Terhadap Peningkatan Keahlian Auditor Dalam Bidang Auditing”. Fakultas Ekonomi Universitas Islam Indonesia Yogyakarta.

Bonner. 1999. Judgment and decision making research in accounting. Journal Accounting Horizons, 13 (3):385-398.

Chung, J. dan G. S. Monroe. 2001. "A Research Note on The Effect of Gender and Task Complexity on Audit judgment". Journal of Behavioral Research, 13: 111-125.

Drupardi, Made, Julia. 2015. "Pengaruh Keahlian Auditor, Tekanan Ketaatan Dan Independensi Pada Audit Judgment". Jurnal Akuntansi Universitas Udayana.12.3 (2015). 623-655.

Efendy, M. Taufiq. 2010. "Pengaruh Kompentensi. Independensi dan Motifasi Terhadap Kualitas Audit Apaarat Inspektorat Dalam Pengawasan Keuangan Daerah". Tesis Magister Sains Akuntansi Universitas Diponegoro Semarang.

Ghozali, Imam. 2011 Aplikasi Analisis Multivariate Dengan Program IBM SPSS Update PLS Regresi Edisi. Diponegoro.

Hartanto, Hansiadi Yuli dan Indra Wijaya Kusuma. 2001. “Analisis Pengaruh Tekanan Ketaatan Terhadap Judgment Auditor". Jurnal Akuntansi dan Manajemen. Ed. Desember, hal 1-14.

Herliansyah, Yudhi dan Meifida Ilyas. 2006. "Pengaruh Pengalaman Auditor Terhadap Penggunaan Bukti Tidak Relevan Dalam Auditor Judgment". Simposium Nasional Akuntansi IX Padang.

Jamilah, Siti, Zaenal Fanani, dan Grahita Chandrarin. 2007. "Pengaruh Gender, Tekanan Ketaatan, dan Kompleksitas Tugas terhadap Audit Judgment". Simposium Nasional Akuntansi X Unhas Makassar.

Magareta, Agnez, Novita. 2014. "Analisis Faktor-Faktor yang Mempengaruhi Audit Judgment pada Auditor BPK RI”. Diponegoro Journal Of Accounting, Vol.3, Nomor 2, Tahun 2014. 
Mayangsari, Sekar. 2003. "Pengaruh Keahlian Audit dan Independensi Terhadap Pendapat Audit: Sebuah Kuasi Eksperimen”. Jurnal Riset Akuntansi Indonesia, Vol. 6 No.1 Januari, hal 1-22.

Mulyadi. 2002. Auditing. Ed.6. Jakarta: Salemba Empat.

Peraturan. Pemerintah Republik Indonesia Nomor 15 Tahun 2004 Tentang Pemeriksaan Pengelolaan dan Tanggung Jawab Keuangan Negara.

Peraturan. Pemerintah Republik Indonesia Nomor 24 Tahun 2005 Tentang Standar Akuntansi Pemerintah (SAP).

Peraturan. Pemerintah Republik Indonesia Nomor 71 Tahun 2010 Tentang Standar Akuntansi Pemerintah (SAP).

Peraturan. 2007 Peraturan BPK-RI Nomor 01 Tahun 2007, tentang Standar Pemeriksaan Keuangan Negara.

Peraturan. 2007 Peraturan BPK-RI Nomor 02 Tahun 2007, tentang Kode Etik.

Praditaningrum, Anugrah Suci. 2012. Analisis Faktor-faktor yang Berpengaruh Terhadap Audit Judgment (Studi pada BPK RI Perwakilan Provinsi Jawa Tengah, Jurnal Simposium Nasional Akuntansi XV. ASP-06.

Puspitasari, Novy. 2010. "Penilaian Hubungan Insentif Kinerja, Usaha, dan Kompleksitas Tugas Terhadap Kinerja Audit Judgment". Fakultas Ekonomi Universitas Diponegoro Semarang.

Rahmawaty, Novita. 2016. "Analisis Faktor-Faktor Yang Mempengaruhi Auditor Dalam Melakukan Audit Judgment". Tesis Universitas Muhammadya Surakarta.

Rahmawi dan Setyaningtyas Honggowati. 2004. "Pengaruh Tekanan Kepatuhan, Gender, Autorarian dan Pertimbangan Moral Terhadap Audit Judgment". Jurnal Bisnis dan Manajemen, Vol 4, No.1, 42-46.

Rochmawati, Vivi Devi. 2009. "Pengaruh Pemahaman Kode Etik Profesi Akuntan dan Pengalaman Audit Terhadap Auditor Judgment". Thesis, Magister Sains Akuntansi Universitas Diponegoro Semarang.

Sugiyono. 2014. Metode Penelitian Kuantitatif Kualitatif dan R\&D. Bandung: Penerbit Alfabeta. Susetyo, Budi. 2009. "Pengaruh Pengalaman Audit Terhadap Pertimbangan Auditor Dengan Kredibilitas Klien Sebagai Variabel Modereting". Tesis, Magister Sains Akuntansi Universitas Diponegoro Semarang.

Suyanto, Dadang. 2013, Aplikasi AUDITING Pemeriksaan Akuntansi, Penerbit CAPS (Center of Academic Publising Service).

Undang-undang No. 15 Tahun 2006 tentang Badan Pemeriksa Keuangan, Penerbit Fokusmedia: Bandung.

Undang-undang No. 23 Tahun 2014 tentang Pemerintahan Daerah, Penerbit Fokusmedia: Bandung.

Wijayatri, Astri. 2010. "Pengaruh Tekanan Ketaatan, Kompleksitas Tugas, dan Keahlian Audit Terhadap Audit Judgment". Fakultas Ekonomi Universitas Pembangunan Nasional Veteran Jawa Timur.

Yustrianthe, Rahmawati Hanny. 2012. "Kajian Empiris Audit Judgement pada Auditor. Media Riset Akuntansi". Vol 2 No.2.

Zulaikha. 2006. "Pengaruh Interaksi Gender, Kompleksitas Tugas, dan Pengalaman Auditor Terhadap Audit Judgment". Simposium Nasional Akuntansi 9 Padang. 